\title{
Functional response of the predatory mite Chileseius camposi (Acarina: Phytoseiidae) on densities of it prey, Panonychus ulmi (Acarina: Tetranychidae)
}

\author{
Francisco Sepúlveda ${ }^{1} \&$ Roberto Carrillo ${ }^{1}$ \\ 1. Instituto de Producción y Sanidad Vegetal, Universidad Austral de Chile,Casilla 567, Valdivia, Chile; rcarrill@uach.cl
}

\author{
Received 24-IV-2007. Corrected 01-II-2008. Accepted 31-VII-2008.
}

\begin{abstract}
The functional response of the phytoseiid predator Chileseius camposi González y Schuster, 1962 (Acarina:Phytoseiidae) on densities of its prey Panonychus ulmi (Koch, 1836) was evaluated under controlled temperature $\left(20 \pm 2{ }^{\circ} \mathrm{C}\right)$, relative humidity $(75 \pm 15 \%)$ and photoperiod $(16: 8 \mathrm{~h} \mathrm{~L}: \mathrm{D})$. A functional type II response was displayed (Holling's disk). Holling, Wolf transformation and Rogers models gave similar values for estimating parameters of the Holling's disk equation; however, estimates produced by the Livdahl and Stiven model were higher. Values of attack rate and handling time can be considered within the normal range for phytoseiid generalists. Rev. Biol. Trop. 56 (3): 1255-1260. Epub 2008 September 30.
\end{abstract}

Key words: Chilesius camposi, Panonychus ulmi, predation, functional response, Phytoseiidae

Chilesius camposi González y Schuster is a dominant phytoseiid mite associated in sympatry with the European red mite Panonychus ulmi (Koch) on apple tree Malus sylvestris Mill., in southern Chile (Venegas 1977, Guajardo 1993). P. ulmi is the most serious pest of apple and other deciduos fruit trees in Chile (Klein and Waterhouse 2000). A review of its biology, pest status and the impact of pesticides on population dynamics are given by Van de Vrie et al. (1972).

Functional response, as described by Solomon (1949), is the change in prey number killed per individual predator per unit of time, as function of changes in prey density. Holling (1959a, 1959b, 1961) proposed three general types of functional response curves: (1) describes a linear rise in prey consumption to a plateau (type I), (2) cyrtoid curve rise at an increasing rate to a plateau (type II), (3) a sigmoid curve with a positive accelerating rate up to the inflection point and thereafter a diminishing rate up to the plateau (type III).
Mori and Chant (1966) proposed a type IV, due they found a dome-shaped response resulting from confusing or inhibiting behavior of a timid predator and the consequent lower rate of attack at high prey densities.

The functional response is one of the most important aspects in the dynamics of a predator-prey relationship, and is a major component of population models (Berryman 1992). It has been used to predict mechanisms underlying predator-prey behavior to improve the practical predictive potential of predator candidates for biological control.

The type II functional response is described by two parameters $a$ (attack rate) and Th (handling time). Thus, accurate parameter estimation becomes a prerequisite to make comparisons consequently, the method of parameter estimation has become a very important and controversial subject.

Therefore, the purposes of this research were to determine the functional response of adult $C$. camposi to varying densities of adult 
female $P$. ulmi under laboratory conditions and to compare different models to estimate $a$ and $T h$.

\section{MATERIALS AND METHODS}

C. camposi and P. ulmi, phytoseiid and tetranychid mites respectively, used in functional response experiments were collected from apple leaves in Valdivia $\left(39^{\circ} 47^{\prime} \mathrm{S}, 73^{\circ} 13^{\prime} \mathrm{W}\right.$ ) $X^{\text {a }}$ Región de Los Lagos, Chile. Leaves were cut from apple trees on February $4^{\text {th }}$ and $28^{\text {th, }}$ 2002. These leaves were taken to the laboratory in large plastic boxes $(30 \times 20 \mathrm{~cm})$ and mites were examined under a dissection microscope. Excess leaves with mites were stored in plastic boxes at $15^{\circ} \mathrm{C}$.

The experimental arena for this research consisted of excised pieces of apple leaf (diameter $2 \mathrm{~cm}$ ) placed underside up, on a Petri dish (diameter $3.5 \mathrm{~cm}$ ) on a water film. To determine the functional responses of the adult stage, $C$. camposi was confined singly on experimental arenas with initial prey densities of $1,5,10$, 20, 30 and 50 per plot. $C$ camposi, is unable to consume spider mite eggs. Each predator was starved for 24 hours before tests. The number of prey killed per individual predator was recorded after $24 \mathrm{~h}$ exposure. The entire experiment was conducted under controlled temperature $\left(20 \pm 2{ }^{\circ} \mathrm{C}\right)$, relative humidity $(75 \pm 15 \%)$ and photoperiod at 16:8h (L:D), respectively. There were 25 replicates per density.

To establish the validity of the outcomes and for comparative purposes, the following curve fitting models were used to estimate the functional response parameters, attack rate coefficient (a) and the handling time (Th) of $C$ camposi preying on European red mite adult female. Sexed female mites were used as prey, to reduce the effect that differential weight of prey should have on the attack rate and handling time of the predator, since different factors may affect the handling time of natural enemies e.g. the speed of predator and prey, the size of the prey and time subduing. a prey (Hassell 1978) Unfortunately was not possible to sex C. camposi, to reduce the possible predator differential attack rate and handling time between males and females.

Holling (1956b):

$$
\left[\frac{N_{a}}{N}=-a T_{h} N+a\right]
$$

Fan and Petitt (1994):

$$
\left[\frac{N=}{N_{a}} T_{h} N+\frac{1}{a}\right]
$$

Rogers (1972: $\left[N_{a}=N\left(1-e^{(-a T+a T}{ }_{h}^{N)}\right)\right]$

Livdahl and Stiven (1983): $\left[\begin{array}{l}\frac{1=1+}{N_{a}} \frac{1}{a N} \\ h\end{array}\right]$

$N_{a}$ defines the number of individual prey attacked per predator per time unit, $N$ is the original number of prey items offered to each predator at the beginning of the experiment, $a^{\prime}$ is the rate of successful attack of prey by a predator, $T_{t}$ is the total time of exposure (24 $\mathrm{h}$ in this experiment), $T_{h}$ is the handling time (proportion of the exposure time that a predator spends in identifying, pursuing, killing, consuming and digesting prey).

Data were analyzed using least squares regression by fitting a line through the data points predicted by the descriptive functional response equation using STATGRAPHICS Plus 5.0.

\section{RESULTS}

An increase in prey density eventually resulted in a higher predation rate. The functional response of $C$. camposi with adult female as prey showed a curvilinear rise to a plateau as seen in Table 1 and Fig. 1. The 
TABLE 1

Prey density and attack parameters

$\begin{array}{cccccc}\mathrm{N}_{\mathrm{o}} & \mathrm{N}_{\mathrm{a}} & N_{\mathrm{H}} & N_{\mathrm{W}} & N_{\text {L\&S }} & N_{\mathrm{R}} \\ 1 & 0.34 \pm 0.06 \mathrm{a} & 0.24 & 0.26 & 0.34 & 0.25 \\ 5 & 1.04 \pm 0.30 \mathrm{~b} & 1.03 & 1.12 & 1.12 & 1.00 \\ 10 & 1.49 \pm 0.46 \mathrm{c} & 1.75 & 1.91 & 1.59 & 1.59 \\ 20 & 2.80 \pm 1.10 \mathrm{~d} & 2.70 & 2.98 & 2.00 & 2.26 \\ 30 & 3.09 \pm 1.08 \mathrm{~d} & 3.30 & 3.66 & 2.19 & 2.62 \\ 50 & 3.38 \pm 1.04 \mathrm{~d} & 4.00 & 4.47 & 2.37 & 3.02 \\ \chi^{2} \text { value } & & 0.198 & 0.304 & 0.491 & 1.134\end{array}$

Initial prey density $\left(\mathrm{N}_{\mathrm{o}}\right)$, observed mean number of prey attacked $\left(\mathrm{N}_{\mathrm{a}}\right)$ and expected number of prey attacked based on Holling (1959b) $\left(N_{\mathrm{H}}\right)$, Woolf transformation $\left(N_{\mathrm{W}}\right)$, Livdahl and Stiven (1983) $\left(N_{\mathrm{L \& S}}\right)$ and Rogers $(1972)\left(N_{\mathrm{R}}\right)$ models. No significant difference between observed and expected number of prey attacked per predator. $\left(\chi^{2}\right.$ goodness of fit test, $\left.\mathrm{p}<0.05\right)$.

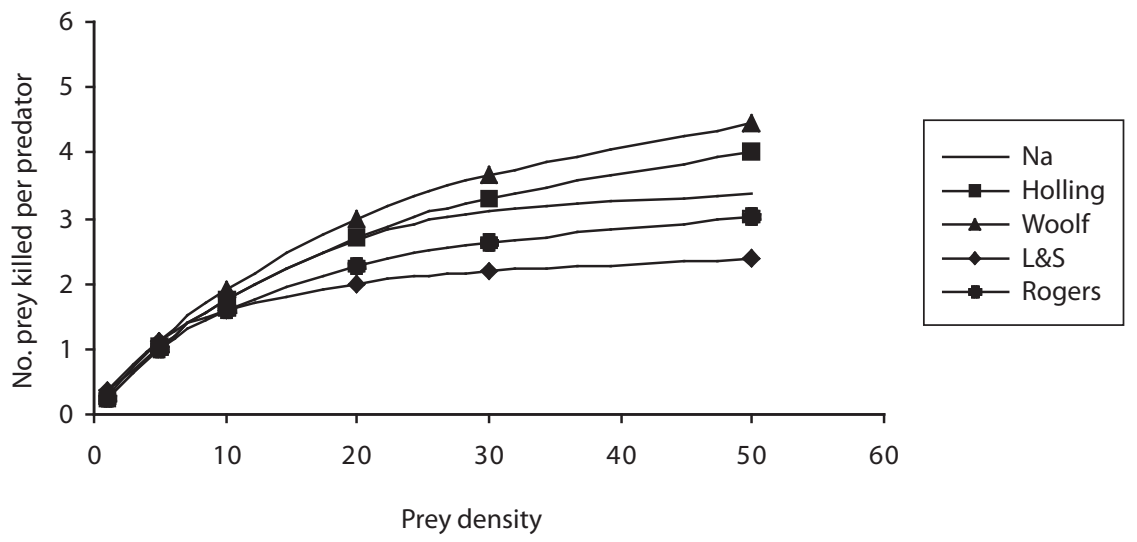

Fig. 1. The number of $P$ ulmi consumed per experiment as a function of the number of $P . u l m i$ available in the experimental plot.

daily feeding of adult $C$. camposi on adult females of $P$. ulmi increased at an accelerated rate when prey density was between 5 and 30 prey. Predation rate started to level off at a prey density of 30-50. The plateau was reached at approximately 3.38 prey items per day.

The average number of adult females consumed by one predator per day was $3.38 \pm 1.04$, ranging from 0 to 6 . Daily predation rate gradually increased when $P$. ulmi were provided at increasing prey densities (Fig. 1).

\section{DISCUSION}

It was clearly demonstrated that increase of prey number was related to the daily consumption number of $P$. ulmi. The predation rate tended to decrease with prey density, probably due to an increasing satiation by predators in patches of higher density. Thus predation rates followed a type II functional response which is shared by most phytoseiid predators (Sabelis 1986). 
However, it is necessary to consider the results with caution because in other experiment, when the excised pieces of leaves were changed to a whole plant system and hence the predators were allowed to disperse from areas of low return (rewards) to more profitable patches of prey, the functional response changed from type II to type III. The functional response type III is the only type that contributes to prey population regulation (Hassell 1976, Hassell 1978).

The predation rate obtained for C. camposi on P. ulmi at the highest density tested, can be considerer similar to the predation rate of generalist phytoseiid predators with lifestyle type III (McMurtry and Croft 1997) such as Amblyseius idaeus Moraes and McMurtry (Cédola and Botto 1996) and Typhlodromus bambusae Ehara (Zhang et al. 1999), and lower than specialized phytoseiid mite predators with life-style type I (Everson 1979, Cédola and Botto 1996).

The expected numbers of consumed prey generated according to each model, are shown in Table 1 and Fig. 1.All the predation models used estimate the expected number of prey consumed similarly. This conclusion is supported by the fractional values of estimated $\mathrm{X}^{2}$ goodness of fit test, which are much lower than the table $\mathrm{X}^{2}$ value of 11.07 at $\mathrm{p}<0.05$ with 5 degrees of freedom (Table 1).

The values of the instantaneous rate of discovery or attack rate coefficient (in units of the proportion of the total prey number consumed or the total area searched) and handling time (in units of the proportion of $24 \mathrm{~h}$ exposure period) for predator attacking adult European red mite females, are shown in Table 2.

Fan and Pettit (1994) found that the Woolf transformation not only linealizes Holling's (1959b) disc equation, but also reduces the variance heterogeneity, thus providing the best parameter estimate among four commonly used linear transformations as well as non-linear regression. Therefore, we considerer the Woolf transformation results in estimating $a$ and $T_{h}$ as the most precise and, hence, the standard of reference among all the models used in
TABLE 2

Parameters of the functional response of C. camposi adults feeding on P. ulmi adults, estimated by four functional response models

$\begin{array}{lcc}\text { Model } & a, & T_{\mathrm{h}} \\ \text { Holling } & 0.24 & 0.16 \\ \text { Wolf transformation } & 0.26 & 0.25 \\ \text { Livdahl and Stiven } & 0.38 & 0.36 \\ \text { Rogers } & 0.26 & 0.14\end{array}$

this study. On this basis, Rogers's (1972) and Holling models generates lower values for handling time i.e. it overestimate this parameter, whereas Livdahl and Stiven's(1983) models overestimate $a$ and underestimate $T_{h}$ (Juliano and Williams 1985, Williams and Juliano 1985, Fan and Pettit 1994).

Aside from the simplicity of the conditions under which these experiments were conducted, the functional response does not by itself show the true regulative power of a predator. Because in spite that the ability of a predator to control depends on the predator's functional and numerical response, this response are influenced by different factors, including behavioral patterns in response to its own densities, developmental response, preference, utilization of alternative prey and intraguild interaction (Lester and Harmsen 2002). So one should take great caution in extrapolating the results of oversimplified laboratory experiments to more complex and heterogeneous field conditions. (O'Neil 1997, Lester and Harmsen 2002). O’Neil (1997) considerer that high prey density laboratory studies focuses attention on predator consumptive behavior, such as handling time, which are not important when prey attacks are low. Nevertheless, due to their relatively good predatory traits, C. camposi is presumably able to be used in conservation biological control approach against European red mite on trees in southern Chile.

At least according to Badii et al. (1999) on the basis of the findings for this predaceous phytoseiid mite, we propose that applied acarologist interested in the control of spider mites by means of the predaceous phytoseiids 
should pay more attention to this species as a very promising (and at the same time a very neglected) candidate for being employed as a biocontrol agent and so enhancing our natural enemy potential.

\section{ACKNOWLEDGMENTS}

This study was supported by the Dirección de Investigación y Desarrollo and the Instituto de Producciòn $\mathrm{y}$ Sanidad Vegetal of the Universidad Austral de Chile.

\section{RESUMEN}

La respuesta funcional del ácaro fitoseido nativo Chileseius camposi González y Schuster, 1962, sobre el ácaro fitófago introducido Panonychus ulmi (Koch, 1836) (Acarina:Tetranychidae) fue evaluada en condiciones controladas de temperatura $\left(20 \pm 2^{\circ} \mathrm{C}\right)$, humedad relativa $(75 \pm$ $15 \%$ ) y fotoperíodo (16:8 h L:O). Una respuesta funcional de tipo II, fue determinada (disco de Holling). Los modelos de Holling, Wolf y Rogers dieron valores similares para la estimación de los parámetros de la ecuación del disco de Holling, la estimación de estos parámetros por el modelo de Livdahl y Stiven fueron mayores. Los valores encontrados para la razón de ataque y el tiempo de manipulación pueden ser considerados dentro del ámbito normal para fitoseidos generalistas.

Palabras clave: Chilesius camposi, Panonychus ulmi, depredación, respuesta funcional, Phytoseiidae.

\section{REFERENCES}

Badii M., J.A. McMurtry \& A Flores. 1999. Rates of development, survival and predation of immature stages of Phytoseilus longipes (Acari: Mesostigmata: Phytoseiidae. Exp. Appl. Acarol. 23: 611-621.

Berryman A. 1992. The origins and evolution of predatorprey theory. Ecology 75: 1530-1535.

Cédola C \& E. Botto. 1996. Evaluación de la respuesta functional de Amblyseius idaeus Moraes y McMurtry, 1983 y Phytoseiulus macropilis (Banks, 1905) (Acarina:Phytoseiidae) en condiciones de laboratorio. Revista Chilena de Entomología 23: 15-18

Everson P. 1979. The functional response of Phytoseiulus persimilis (Acarina: Phytoseiidae) to various densities of Tetranychus urticae (Acarina: Tetranychidae). Canadian Entomologist 111: 7-10.

Fan Y \& F. Petit. 1994 Parameter estimation of functional response. Environmental Entomologist 23: 785-794.

González R \& R. Schuster. 1962. Especies de la familia Phytoseiidae en Chile I. (Acarina:Mesostigmata). Universidad de Chile, Facultad de Agronomía. Universidad de Chile Boletín Técnico No 16

Guajardo M. 1993. Acaros asociados a un huerto de manzanos de la la Décima Región y su respuesta a diferentes insecticidas con distinto sitio de acción. Tesis de Licenciatura, Facultad de Ciencias Agrarias, Universidad Austral de Chile, Valdivia, Chile.

Hassell M. 1976. Arthropod predator-prey systems, p 105-131. In May R (ed.) Theoretical ecology, principles and applications. Second edition. Blackwell ScientificPublications, Oxford, United Kingdom.

Hassell M. 1978. The dynamics of arthropod predator-prey systems. Princenton University Press, Princenton, New Jersey, USA.

Holling C. 1959a. The components of predation as revealed by a study of small-mammal predation of the European pine sawfly. Canadian Entomologist 91: 293-320.

Holling C. 1959b. Some characteristics of simple types of predation and parasistism. Canadian Entomologist 91:385-398.

Holling C. 1961. Principles of insect predation. Annu. Rev. Entomol. 6:163-182.

Juliano S. \& F. Williams. 1985. On the evolution of handling time. Evolution 39:212-215.

Klein C. \& D. Waterhouse. 2000. The distribution and importance of arthropods associated with agriculture and forestry in Chile. ACIAR Monograph $N^{\circ} 68$.

Lester P. \& R. Harmsen. 2002. Functional and numerical responses not always indicate the most effective predator for biological control: an analysis of two predators in a two-prey system. Journal of Applied Ecology 39:455-468.

Livdahl T. \& A. Stiven. 1983. Statistical difficulties in the analysis of predator functional response data. Canadian Entomologist 115: 1365-1370.

McMurtry J. \& D. Croft.1997. Life styles of Phytoseiid mites and their roles as biological control agents. Annu. Rev. Entomol. 42: 291-321.

Mori H. \& D. Chant. 1966. The influence of prey density, relative humidity and starvation on the predaceous 
behavior of Phytpseiulus persimilis Athias-Henriot (Acarina: Phytoseiidae). Canadian Journal of Zoology 44:483-491.

O’Neil R. 1997. Functional response and search strategy of Podissus maculiventris (Heteroptera: Pentatomidae) attacking Colorado Potato Beetle (Coleoptera: Chrysomelidae). Environmental Entomology 26: 1183-1190.

Rogers D. 1972. Random search and insect population models. Journal of Animal Ecology 18:1-35.

Sabelis M. 1986. The functional response of predatory mites to the density of two spider mites, p.298321. In Metz J. \& Diekmann O. (eds.). Dynamics of Physiologically Structured Populations, Lecture Notes in Biomathemathics. Springer Verlag, Belin, Germany.

Solomon M. 1949. The natural control of animal populations. Journal of Animal Ecology 41: 369-383.
Van De Vrie M., JMcMurtry \& C. Huffaker. 1972. Ecology of tetranychid mites and their natural enemies: a review. III: Biology, ecology and pest status and host-plant relation of tetranychid. Hilgardia 41: 343-432.

Venegas C. 1977. Biology, population dynamic and antagonists of some apple phytophagous insects and mites (Malus pumila Mill.) in Valdivia. Tesis de Ingeniero Agrónomo, Facultad de Ciencias Agrarias, Universidad Austral de Chile, Valdivia, Chile.

Williams F. \& S. Juliano. 1985. Further difficulties in the analisis of functional response experiments and resolution. Canadian Entomologist 117:631-640.

Zhang Y., Z. Zhang, J. Lin \& Q. Liu. 1999. Biology of Typhlodromus bombusae (Acari: Phytoseiidae) a predator of Schizotetranychus nanjingensis (Acari: Tetranychidae) injurous to bamboo in Funjian, China. Systematic Applied Acarology 4: 57-62. 